\title{
Alfaites romeo gen. et sp. nov., a new Hyolitha from the Cambrian of Skryje-Týřovice Basin (Czech Republic)
}

\author{
Martin VALENT ${ }^{1, *}$, Oldřich FATKA ${ }^{2} \&$ Ladislav MAREK ${ }^{3}$ \\ ${ }^{1}$ National Museum, Palaeontological Department, Cirkusová 1740, 19300 Prague 9, Czech Republic. \\ ${ }^{2}$ Charles University, Faculty of Science, Institute of Geology and Palaeontology, Albertov 6, \\ 128 43, Prague 2, Czech Republic. \\ ${ }^{3}$ Deceased 18 Feb 1995. Institute of Geology of the Czech Academy of Sciences, \\ Rozvojová 269, 16500 Prague 6 - Lysolaje, Czech Republic. \\ *Corresponding author: martin_valent@nm.cz \\ 2Email: fatka@natur.cuni.cz \\ ${ }^{1}$ urn:Isid:zoobank.org:author:1F485352-EC53-40DA-AF42-317CBE6A7B48 \\ ${ }^{2}$ urn:lsid:zoobank.org:author:40950230-AEAD-47E9-9A59-EB3E7F76E6FA \\ ${ }^{3}$ urn:Isid:zoobank.org:author:1624511B-F2C2-4964-A4D2-CF072FF24D61
}

\begin{abstract}
The rare hyolith Alfaites romeo gen. et sp. nov. is described from the lower half of the middle Cambrian (Drumian) Buchava Formation of the Skryje-Týrovice Basin in the Barrandian area of the Czech Republic. This new taxon is based on excellently preserved external and internal moulds of three opercula and several conchs collected from carbonate nodules and shale. This rare species has been established at three separate outcrops in the lower part of the Biozone of Paradoxides (Eccaparadoxides) pusillus (Barrande 1846). Morphology of conch and both external and internal surface of operculum are well known. However, specific morphology excludes assignment to any predescribed hyolithid family.

Keywords. Hyolitha, Alfaites, Drumian, Cambrian Series 3, Skryje-Týřovice Basin, Barrandian area, Czech Republic.

Valent M., Fatka O. \& Marek L. 2019. Alfaites romeo gen. nov. et sp. nov., a new Hyolitha from the Cambrian of Skryje-Týřovice Basin (Czech Republic). European Journal of Taxonomy 491: 1-10.

https://doi.org/10.5852/ejt.2019.491
\end{abstract}

\section{Introduction}

Hyoliths represent a group of extinct Palaeozoic invertebrates with originally aragonitic shells whose precise systematic affinity remains unclear.

The group Hyolitha is usually divided into two main orders. The order Orthothecida Marek, 1966 represents hyoliths with a conical shell of diverse cross-section (circular, elliptical, kidney-shape...) and planar aperture with retractable planar or slightly concave operculum. The order Hyolithida Sysoev, 1957 is characterized by a shell of diverse cross-section (triangular, oval, etc.) with prolonged venter, 
corresponding non-retractable operculum and paired curved appendages called helens which protrude from the spaces between conch and operculum.

Hyoliths have been often classified as incertae sedis (e.g., Bengston et al. 1990; Devaere et al. 2014), as a group of mollusks (e.g., Malinky \& Yochelson 2007; Marek \& Yochelson 1976) or as a separate phylum (e.g., Kouchinsky 2000; Runnegar et al. 1975). The taxonomic placement of hyolithids was recently discussed by Martí Mús (2016) and Moysiuk et al. (2017), who suggested that hyoliths show a strong affinity to the Palaeozoic lophophorates, mainly to brachiopods. This interpretation was based on excellently preserved hyolithid material with clearly distinct soft parts. The recent paper of Moore \& Porter (2018) supports this statement based on study of the microstructure of conchs and opercula.

The lower to middle stratigraphical levels of the Buchava Formation of the Skryje-Týřovice Basin (Barrandian area, Czech Republic) have yielded abundant remains of diverse skeletal fauna (Barrande 1852, 1867; Šnajdr 1958; Fatka et al. 2011), including exceptionally well-preserved hyoliths (e.g., Martí Mús \& Bergström 2005).

In the second half of the twentieth century, a large collection of several hundred hyolith conchs and opercula was gathered by Petr Šlehofer and Ladislav Marek (Academy of Science Prague) at numerous outcrops of the Skryje-Týřovice Basin (Marek 1983). Some of these materials were described in a series of papers by Marek (1972, 1975, 1980, 1981; see also summary by Malinky \& Yochelson 2007). This extensive collection was transferred from the Academy of Science to the National Museum, Prague, in 1998. Here, the original hyolith material was newly sorted and specimens belonging to still-undescribed or poorly known taxa were selected for study, leading to the successful description of material from Marek's original collection (Valent et al. 2013, 2017).

Insufficient material of other species has been complemented by more recently collected specimens and described by a team of authors, particularly by the amateur collectors Václav Micka (Prague), Michal Szabad (Př́bram) and Václav Vokáč (Plzeň), who provided additional specimens and important data on geographic and stratigraphic distribution of individual taxa (Valent et al. 2011, 2012).

The aim of this contribution is to describe the new hyolithid Alfaites romeo gen. et sp. nov. recognized by the late Ladislav Marek in an unpublished manuscript dating from the early 1980s (Marek 1983). This rare form is restricted to the Biskoupky, Buchava and Hradiště localities in the Skryje-Týřrovice Basin.

The Skryje-Týřrovice Basin is one of several regions where Cambrian fossils are known in the Czech Republic (Fig. 1A-B; Geyer et al. 2008). Middle Cambrian sediments of the Buchava Formation belong to a classical repository of Cambrian fauna (Geyer et al. 2008), present in outcrops at the north-western edge of the Late Cambrian Křivoklát-Rokycany Volcanic Complex (Fig. 1C-D).

\section{Material and methods}

\section{Distribution}

Alfaites romeo gen. et sp. nov. has been reported from the Biskoupky, Buchava, and Hradiště localities, all situated in the south-western part of the Skryje-Týrovice Basin (Fig. 1D).

Biskoupky locality. The small outcrop of Cambrian sediments north-west of the village Biskoupky represents the westernmost occurrence of the Skryje-Týrovice Basin (Smetana 1920; Fatka et al. in press; Fig. 1D herein). The geological setting of the Biskoupky locality as well as its geographic and palaeogeographic situation, including a comprehensive research history of associated skeletal fauna and ichnofossils, were recently summarized and discussed by Fatka et al. (in press) and Valent et al. (2017). 


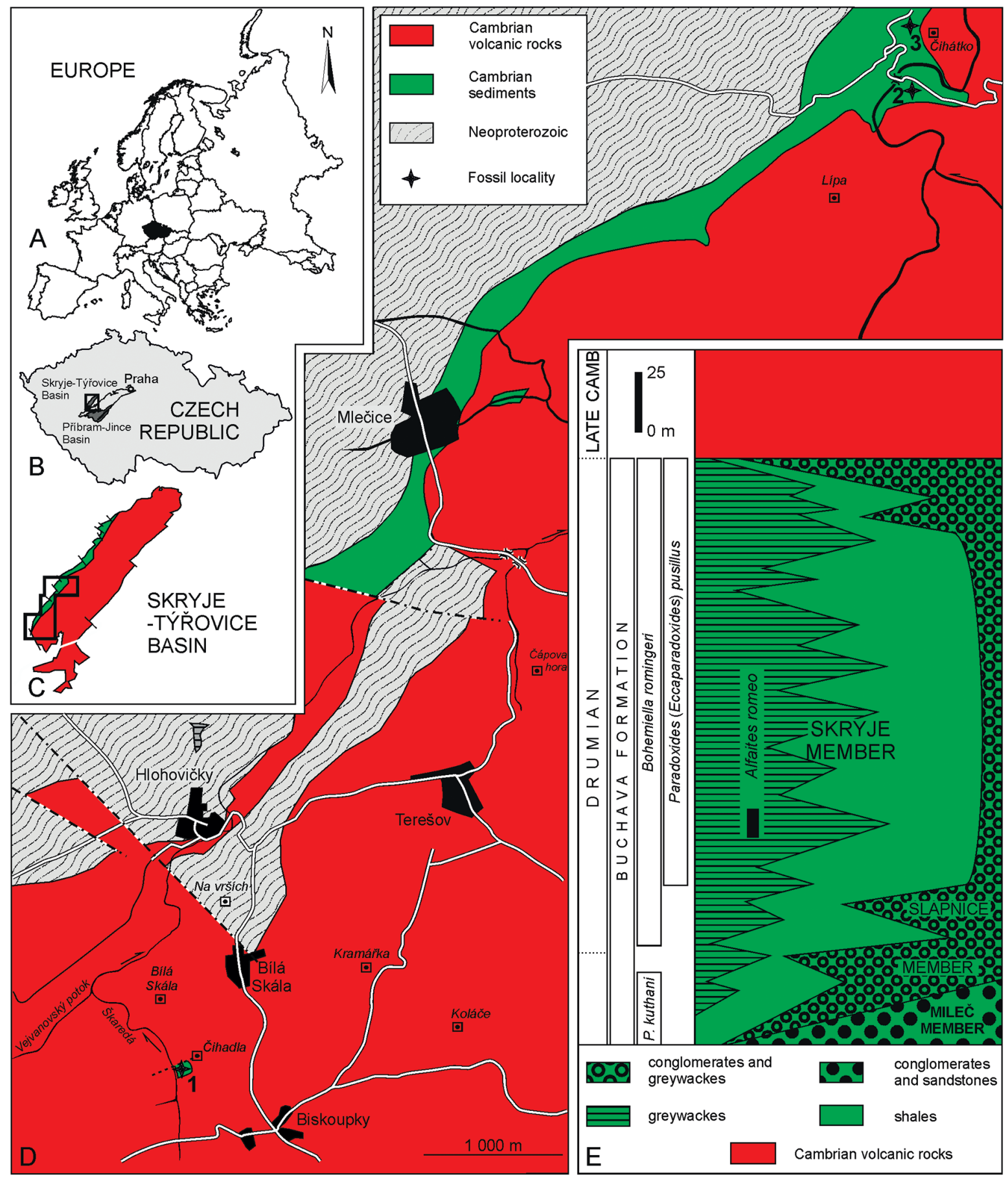

Fig. 1. Maps showing the location of fossil sites in the middle Cambrian Buchava Formation within the Skryje-Týřovice Basin, Central Bohemia. A. Map of Europe with the Czech Republic. B. Map of the Czech Republic showing distribution of Palaeozoic rocks of Barrandian area. C. Simplified sketch map of the Skryje-Týřovice Basin. D. Geological map showing distribution of middle Cambrian Buchava Formation and location of the Buchava, Hradiště and Biskoupky localities. E. Stratigraphic position of the Buchava, Hradiště and Biskoupky localities and range of Alfaites romeo gen. et sp. nov. Geology modified from Mašek et al. (1997) and Vorel et al. (2014); lithostratigraphy and biostratigraphy after Fatka et al. (2011) and Vokáč (2002). 1 = Biskoupky locality; 2 = Buchava locality; 3 = Hradiště locality. 
Buchava locality. Fossils from the wider area of the forester's lodge at Slapy were already known to Barrande as the locality "Podmokl" (see Šnajdr 1958: 26; Chlupáč 1999: 10-11). This outcrop was discussed by Pompeckj (1896) and Jahn (1896: 742), who stressed the abundant occurrence of hyoliths at their locality 17 - "Steinbruch Buchava beim Hegerhaus Slapy". Šnajdr (1958: 26) called this locality "Podmokelský mlýn", while Marek (1975) preferred the name "Buchava". Jahn (1896: 743-744) and Marek (1975: 64) compiled exhaustive lists of established species and reported the discovery of a layer with concretions containing abundant and extraordinarily preserved hyoliths, particularly of the species Maxilites maximus (Barrande, 1867).

Hradiště locality. Natural outcrops in a forested hill-slope belonging to the lower third of the Buchava Formation (Fig. 1E). This outcrop was mentioned by Valent et al. (2015) as one of the localities yielding the rare hyolithids Skryjelites auritus Valent et al., 2015 and Quasimolites quasimodo Valent et al., 2015.

The occurrence of the agnostid Peronopsis associated with Paradoxides (Eccaparadoxides) pusillus (Barrande, 1846), diverse paradoxidid and other trilobites, brachiopods and echinoderms established at the Biskoupky, Buchava and Hradiště localities (for the list of associated taxa at Biskoupky see Fatka et al. in press; at Buchava see Marek 1975), indicates a biostratigraphic age equivalent to the Caesaraugustian Regional Stage in the West Gondwanan chronostratigraphic scale (see Geyer et al. 2008) and thus corresponds to the Drumian Stage of Cambrian Series 3 (Fig. 1E).

\section{Photography and collection}

The specimens were studied using an Olympus SZX-12 optical stereo zoom microscope. External moulds and latex casts were coated with ammonium chloride and photographed using an Olympus DP72 digital camera. Helicon Focus software was used to stack the images for sufficient depth of focus. All illustrated specimens are held in the collections of the Palaeontological Department, National Museum, Cirkusová 1740, 19300 Praha 9 - Horní Počernice, Czech Republic, registered with the prefix NM L. The material was collected by the late Ladislav Marek and Pavel Šlehofer (Czech Academy of Science).

\section{Repository}

$\mathrm{NM}=$ National Museum, Prague, Czech Republic

\section{Results}

Class Hyolitha Marek, 1963

Order Hyolithida Sysoev, 1957

Family unknown

Alfaites gen. nov. urn:1sid:zoobank.org:act:6CCEF3A7-D24B-4777-9E08-BFB8DCF68F87

\section{Type species}

Alfaites romeo sp. nov.

\section{Etymology}

The name 'Alfaites' refers to the first letter of Greek alphabet - alpha. The cross-section of the conch (Fig. 2H) resembles the large letter alpha and the small letter alpha (turned $90^{\circ}$ clockwise) can also be discerned in Fig. 2C. 


\section{Diagnosis}

Conch with almost flat slopes of dorsal side; dorsal side broadly rounded; ventral side very slightly vaulted to almost flat; lateral edges sharply rounded. Subtriangular cross-section. Amblygonal aperture. Sculpture of conch consists of transverse rarely anastomosing ribs. No apical septa were found.

Monoclaviculate operculum with clavicles of bow-shaped transverse cross-section. Open margins of clavicles overlap above inner surface operculum (interclavicular concavity). Distal ends of clavicles cut off. Bases of cardinal processes diverge at $90^{\circ}$ angle. Uncommon and relatively robust cardinal teeth developed along the dorsal margin. Rooflets distinct. Sculpture of operculum consisting of growth-lines and fine radial ribs.

\section{Occurrence}

Buchava Formation, middle Cambrian, Drumian, Skryje-Týřovice Basin, Barrandian area, Czech Republic.

\section{Remarks}

Morphology of both conch and operculum does not allow the classification of Alfaites gen. nov. to any known family of the order Hyolithida. This genus resembles Carinolithes Sysoev, 1958 as emended by Berg-Madsen \& Malinky (1999) in the morphology of the cardinal processes, but the operculum of Alfaites gen. nov. is monoclaviculate, thus differing from the platyclaviculate operculum of Carinolithes. Similarly, the shape of the transverse cross-section of the conch (subtriangular in Alfaites and rounded -triangular with distinct keel on dorsum in Carinolithes) and the sculpture (distinct transverse ribs in Alfaites and usually fine growth-lines in Carinolithes) are different. The genus Alfaites, including its type species $A$. romeo sp. nov., was first recognized as a separate taxon in an unpublished report by the late Ladislav Marek (1983: 36-38).

Alfaites romeo gen. et sp. nov. urn:Isid:zoobank.org:act:2EA9355A-4894-4F7B-AFDA-1000BCE24C3C

Fig. 2

\section{Etymology}

The specific epithet 'romeo' refers to the Shakespeare's protagonist Romeo Montague. Marek initially planned to describe two closely related taxa as $A$. romeo and A. julia. The only specimen designated as A. julia (Fig. 2D) in the original collection of L. Marek does not show any difference in morphology and should be classified as $A$. romeo.

\section{Material examined}

\section{Holotype}

CZECH REPUBLIC - Skryje-Týřovice Basin • Inner side of operculum; NM L46640.

\section{Paratypes}

CZECH REPUBLIC - Skryje-Týřrovice Basin • Inner side of operculum; NM L46642 • External sides of operculum; NM L46646, NM L46641 • Inner mould of conch; NM L46645 • External moulds of conchs; NM L46643, L46644.

\section{Referred material}

In addition to the holotype and paratypes, parts of another three conchs and five opercula (collection NM Ls 858), all deposited in collections of the National Museum (Prague, Czech Republic). 

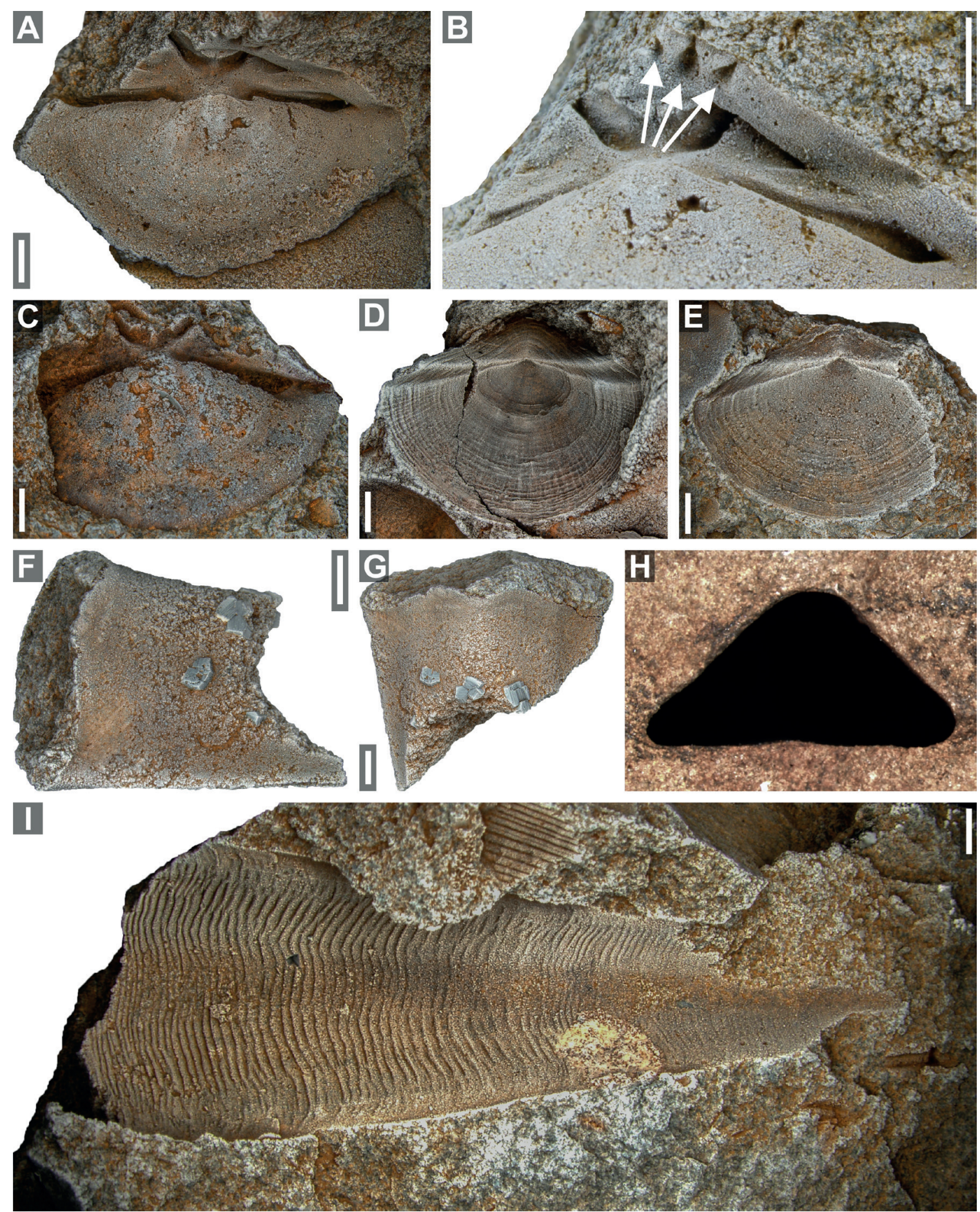

Fig. 2. Alfaites romeo gen. et sp. nov. A-B. Holotype (NM L46640). A. Outer mould of internal side of operculum. B. Detail of outer mould of internal side of operculum with marked cardinal teeth. $\mathbf{C}-\mathbf{I}$. Paratypes. C. Outer mould of internal side of operculum (NM L46642). D. Outer mould of external side of operculum (NM L46646). E. Outer mould of external side of operculum (NM L46641). F. Outer mould of apertural part of conch - lateral view (NM L46645). G. Inner mould of apertural part of conch - dorsal view (NM L46645). H. Subtrigonal cross-section of conch (NM L46643). I. Outer mould of dorsal side of conch with distinct asymmetrical ribs (NM L46644). Scale $=1 \mathrm{~mm}$. 


\section{Type horizon}

Paradoxides (Eccaparadoxides) pusillus Zone, Skryje Member, Buchava Formation, Drumian, middle Cambrian, Barrandian area, Czech Republic.

\section{Diagnosis}

As for the genus.

\section{Description}

Monoclaviculate operculum with clavicles of bow-shaped transverse cross-section. The angle of divergence of clavicles reaches $135^{\circ}$ on the type specimen (NM L46640). Open margins of clavicles overlap above the inner surface operculum (interclavicular concavity). Distal ends of clavicles cut off. Cardinal processes broadly divergent with rounded distal ends, mutually separated by a narrow and shallow groove in linear axis of operculum. Bases of cardinal processes diverging at an angle of $90^{\circ}$ toward the dorsal margin of operculum. Uncommon and relatively robust cardinal teeth are developed along the dorsal margin. Cardinal shield is concave in centre and slightly vaulted at the sides. Rooflets clearly distinct and bordered by grooves. Sculpture of operculum consists of growth-lines and fine radial ribs, more distinct near anterior margin of conical shield. Area of operculum adjacent to summit of operculum is nearly smooth. Width and length of inner side operculum is $8.8 \mathrm{~mm}$ and $5.5 \mathrm{~mm}$ for holotype NM L44640, $7.7 \mathrm{~mm}$ and $4.7 \mathrm{~mm}$ for paratype NM L44642; width and length of outer side of operculum is $7.6 \mathrm{~mm}$ and $4.9 \mathrm{~mm}$ for paratype NM L44641 and $6.7 \mathrm{~mm}$ and $4.7 \mathrm{~mm}$ for paratype NM L44646. Length of the conical shield is $4.0 \mathrm{~mm}$ for paratype NM L44641 and $3.7 \mathrm{~mm}$ for paratype NM L44646.

Conch with subtriangular cross-section. Ventral side very slightly vaulted to almost flat; lateral edges sharply rounded; dorsal side strongly rounded. Amblygonal aperture with dorsal margins vaulted slightly forwardly. The w/h index of conch at aperture is 2.2 (width of aperture of specimen NM L46645 is $7.1 \mathrm{~mm}$ and height is $3.2 \mathrm{~mm}$ ). No apical septa were found. Sculpture consists of transverse rarely anastomosing ribs, which are asymmetrical in transverse cross-section. Ventral side bears only indistinct growth-lines. Conch attained minimum length $30 \mathrm{~mm}$.

\section{Occurrence}

This rare species has been found only at the Biskoupky, Buchava and Hradiště localities.

\section{Remarks}

In his manuscript, Marek (1983) stated that the material collected from the above localities contained another species closely related to Alfaites romeo sp. nov., but presenting opercula with distinctly more vaulted conical shields, higher cardinal shields and a more rounded outline. He even marked the box of one specimen (NM L46646, Fig. 2D) as "Alfaites julia" sp. nov., but no significant differences could be observed upon study of the available material.

\section{Discussion}

The Cambrian fossils of the Barrandian region have been intensively collected and studied since the beginning of the $19^{\text {th }}$ century. Despite such a long tradition, careful collecting still provides undescribed invertebrate taxa like those occurring only at several localities and/or those restricted exclusively to one small outcrop (e.g., Fatka \& Herynk 2016; Valent et al. 2017). The late Dr Ladislav Marek (in cooperation with P. Šlehofer) gathered a large collection of Cambrian and Ordovician hyoliths. The Cambrian hyolith material was colleted from numerous "classical" and well known outcrops as well as from small and occasional excavations. The acquired material was only partly published (Marek 1972, 1975, 1980, 1981), while the larger part of Marek's study was summarized in an unpublished report 
(Marek 1983). Thanks to the monograph of Barrande (1867) and the more recent studies of Marek (1972-1981), Cambrian hyoliths of the Barrandian area represent a classical repository of this group. The hyolith taxa first distinguished by Marek have since been completed by more recently collected specimens and published one by one (Valent et al. 2011, 2012, 2013, 2015, 2017).

\section{Acknowledgements}

The authors thank F. Debrenne (CNRS-MNHN Paris, France) and an anonymous reviewer for their helpful reviews and linguistic improvements to our text. This research was supported by the Ministry of Culture of the Czech Republic - DKRVO 2019-2023/2.IV.a, National Museum, 00023272 (M. Valent) and by PROGRES Q45 of the Ministry of Education, Youth and Sports of the Czech Republic. This is a contribution to IGCP 653 "Filling the gap between the Cambrian Explosion and the GOBE".

\section{References}

Barrande J. 1852. Systême silurien du centre de la Bohême. Ière partie: Recherches paléontologiques. Vol. 1. Crustacés: trilobites. Published by the author, Prague/Paris.

Barrande J. 1867. Systême silurien du centre de la Bohême. Vol. 3. Classe des Mollusques, Ordre des Ptéropodes. Published by the author, Prague/Paris.

Bengston S., Conway Morris S., Cooper B., Jell P. \& Runnegar B. 1990. Early Cambrian fossils from South Australia. Memoirs of the Association of Australasian Palaeontologists 9: 345-364.

Berg-Madsen V. \& Malinky J.M. 1999. A revision of Holm's Mid and Late Cambrian hyoliths of Sweden. Palaeontology 42 (5): 841-885.

Chlupáč I. 1999. Barrande's stratigraphic concepts, palaeontological localities and tradition - comparison with the present state. Journal of the Czech Geological Society 44 (1-2): 3-30.

Devaere L., Clausen S., Álvaro J.J., Peel J.S. \& Vachard D. 2014. Terreneuvian orthothecid (Hyolitha) digestive tracts from northern Montagne Noire, France; taphonomic, ontogenetic and phylogenetic implications. PLoS One 9: e88583. https://doi.org/10.1371/journal.pone.0088583

Fatka O. \& Herynk J. 2016. The first report of the bivalved arthropod Tuzoia from the Skryje-Týrývice Basin (Barrandian area, Czech Republic). Annales de Paleontologie 102 (4): 219-224.

https://doi.org/10.1016/j.annpal.2016.10.002

Fatka O., Micka V., Szabad M., Vokáč V. \& Vorel T. 2011. Nomenclature of Cambrian lithostratigraphy of the Skryje-Týŕovice Basin. Bulletin of Geosciences 85 (4): 841-858.

https://doi.org/10.3140/bull.geosci.1284

Fatka O., Vokáč V., Mikuláš R. In press. A review of taxa recorded at the Biskoupky locality (Cambrian, Barrandian area, Czech Republic). Carnets de Géologie (Notebooks on Geology).

Geyer G., Elicki O., Fatka O. \& Żylińska A. 2008. Cambrian. In: McCann T. (ed.) Geology of Central Europe: 155-202. Geological Society of London, London.

Jahn J.J. 1896. Ueber die geologischen Verhältnisse des Cambrium von Tejřovic un Skrej in Böhmen. Jahrbuch der Keiserlichen-königlichen geologischen Reichsanstalt 45 (4): 641-790.

Kouchinsky A.V. 2000. Skeletal microstructures of hyoliths from the early Cambrian of Siberia. Alcheringa 24: 65-81.

Malinky J.M. \& Yochelson E.L. 2007. On the systematic position of the Hyolitha (Kingdom Animalia). Memoirs of the Association of Australasian Palaeontologists 34: 521-536. 
Marek L. 1963. New knowledge on the morphology of Hyolithes. Sbornik geologických Véd, Paleontologie 1: 53-73.

Marek L. 1966. New hyolithid genera from the Ordovician of Bohemia. Časopis Národního Muzea 135: 89-92.

Marek L. 1972. Middle Cambrian hyolithes Maxilites gen. nov. Časopis Národního Musea, oddíl prírodovédný 141 (1-2): 69-72.

Marek L. 1975. Objev nové hyolithové fauny ve skryjsko-týřovickém kambriu [The discovery of a new hyolithid fauna in the Skryje-Týrovice Cambrian]. Bohemia centralis 4: 64-71.

Marek L. 1980. Slapylites gen. nov. from the Bohemian Middle Cambrian. Časopis Národního Musea, oddil prírodovědný 149 (3): 156-160.

Marek L. 1981. Middle Cambrian hyolithid family Parentilitidae fam. nov. Časopis Národního Musea, oddíl prírodovědný 150 (3): 163-168.

Marek L. 1983. Hyoliti českého středniho kambria [Hyoliths of the Bohemian Middle Cambrian]. Unpublished manuscript. Czech Geological Institute of Geology and Geotechnics of the Czech Academy of Sciences.

Marek L. \& Yochelson E.L. 1976. Aspects of the biology of Hyolitha (Mollusca). Lethaia 9: 65-82. https://doi.org/10.1111/j.1502-3931.1976.tb00952.x

Martí Mús M. 2016. A hyolithid with preserved soft parts from the Ordovician Fezouata KonservatLagerstätte of Morocco. Palaeogeography, Palaeoclimatology, Palaeoecology 460: 122-129. https://doi.org/10.1016/j.palaeo.2016.04.048

Martí Mús M. \& Bergström, J. 2005. The morphology of hyolithids and its functional implications. Palaeontology 48 (6): 1139-1167. https://doi.org/10.1111/j.1475-4983.2005.00511.x

Mašek J., Straka J., Hrazdíra P., Pálenský P., Štěpánek P., Hůla P. 1997. Geological and nature conservation map. Protected Landscape Area and Biosphere Reserve Křivoklátsko. Prague.

Moore J.L. \& Porter S.M. 2018. Plywood-like shell microstructures in hyoliths from the middle Cambrian (Drumian) Gowers Formation, Georgina Basin, Australia. Palaeontology 61 (3): 441-467. https://doi.org/10.1111/pala.12352

Moysiuk J., Smith M.R. \& Caron J.-B. 2017. Hyoliths are Palaeozoic lophophorates. Nature 541: 394 397. https://doi.org/10.1038/nature20804

Pompeckj J.F. 1896. Die Fauna des Kambriums von Tejřovic und Skrej in Böhmen. Jahrbuch der Keiserlichen-königlichen geologischen Reichsanstalt 45: 495-615.

Runnegar B., Pojeta J., Morris N.J., Taylor J.D., Taylor M.E. \& McClung G. 1975. Biology of the Hyolitha. Lethaia 8: 181-191.

Smetana V. 1920. Kambrium u Biskoupek na Zbirožsku [Cambrian in the Zbiroh area]. Rozpravy II. třídy České akademie 28 (23): 1-4.

Šnajdr M. 1958. Trilobiti českého středního kambria [Bohemian Middle Cambrian trilobites]. Rozpravy Ústředního ústavu geologického 24: 1-280.

Sysoev A.V. 1957. K morfologii, sistematicheskomu polozheniyu i sistematike khiolotov [On the morphology, systematic position and systematics of hyoliths]. Doklady Akademii nauk SSSR 116 (2): 304-307.

Sysoev A.V. 1958. The superorder Hyolithoidea. In: Luppov N.P. \& Drushits V.V. (eds) Principles of Palaeontology. Mollusca, Cephalopoda 6: 184-190. Akademia Nauk, SSSR, Moscow. 
Valent M., Fatka O. \& Marek L. 2013. Gracilitheca and Nephrotheca in the Cambrian of the Barrandian area (Hyolitha, Orthothecida, Czech Republic). Alcheringa 37 (1): 115-124.

https://doi.org/10.1080/03115518.2012.709446

Valent M., Fatka O. \& Marek L. 2017. Biskolites iactans gen. et sp. nov. from the Cambrian of the Czech Republic (Hyolitha, Skryje-Týřovice Basin). Neues Jahrbuch für Geologie und Paläontologie 285 (2): 227-233. https://doi.org/10.1127/njgpa/2017/0679

Valent M., Fatka O., Szabad M., Micka V. \& Marek L. 2012. Two new orthothecids from Cambrian of the Barrandia area (Hyolitha, Skryje-Týřovice Basin, Czech Republic). Bulletin of Geosciences 86 (2): 241-248. https://doi.org/10.3140/bull.geosci.1142

Valent M., Fatka O., Szabad M., Micka V. \& Marek L. 2015. Skryjelites auritus gen. et sp. nov. and Quasimolites quasimodo gen. et sp. nov. - two new middle Cambrian hyolithids (?Mollusca) from the Czech Republic. Zootaxa 4007 (3): 419-426. https://doi.org/10.11646/zootaxa.4007.3.8

Valent M., Fatka O., Szabad M. \& Vokáč V. 2011. Carinolithidae fam. nov., Carinolithes bohemicus sp. nov. and Slehoferites slehoferi gen. et sp. nov. - new hyolithid taxa from the Bohemian middle Cambrian (Skryje-Týřovice Basin Czech Republic). Palaeobiodiversity and Palaeoenvironments 91 (2): 101-109. https://doi.org/10.1007/s12549-011-0049-1

Vokáč V. 2002. Poznámky k biostratigrafii jineckého souvrství (střední kambrium) v skryjsko-týřovickém regionu (Barrandien, Čechy) [Remarks on the biostratigraphy of the Jince Formation (Middle Cambrian) from the Skryje-Týřovice region (Barrandian, Bohemia)]. Palaeontologia Bohemiae 8 (6): 117-118.

Vorel T., Hradecký P., Stárková M. \& Holásek O. 2014. Základní geologická mapa České republiky 1:25 000, list 12-323 Podmokly [Basic geological map of the Czech Republic 1:25 000, sheet 12-323 Podmokly]. Czech Geological Survey, Praha.

Manuscript received: 20 July 2018

Manuscript accepted: 12 December 2018

Published on: 24 January 2019

Topic editor: Christian de Muizon

Desk editor: Eva-Maria Levermann

Printed versions of all papers are also deposited in the libraries of the institutes that are members of the EJT consortium: Muséum national d'Histoire naturelle, Paris, France; Meise Botanic Garden, Belgium; Royal Museum for Central Africa, Tervuren, Belgium; Natural History Museum, London, United Kingdom; Royal Belgian Institute of Natural Sciences, Brussels, Belgium; Natural History Museum of Denmark, Copenhagen, Denmark; Naturalis Biodiversity Center, Leiden, the Netherlands; Museo Nacional de Ciencias Naturales-CSIC, Madrid, Spain; Real Jardín Botánico de Madrid CSIC, Spain; Zoological Research Museum Alexander Koenig, Bonn, Germany. 